\title{
Toxicology Studies on Lewisite and Sulfur Mustard Agents: Mutagenicity of Lewisite in the Salmonella Histidine Reversion Assay
}

\section{Final Report}

\author{
D. L. Stewart, E. J. Sass, L. K. Fritz and L. B. Sasser \\ Pacific Northwest Laboratory, P.O. Box 999 \\ Richland, WA 99352-0999
}

July 31, 1989

Supported by

U.S. Army Medical Research and Development Command

Fort Detrick, Frederick, MD 21701-5012

Army Project Order No. 84PP4865

Contracting Officer's Representative:

Jack C. Dacre, Ph.D., D.Sc. Health Effects Research Division

U.S. Army Biomedical Research and Development Laboratory

Fort Detrick, Frederick, MD 21701-5010

Approved for public release; distribution unlimited

The findings in this report are not to be construed as an official Department of the Army position unless so designated by other authorized documents. 


\title{
DISCLAIMER
}

This report was prepared as an account of work sponsored by an agency of the United States Government. Neither the United States Government nor any agency thereof, nor Battelle Memorial Institute, nor any or their employees, makes any warranty, expressed or implied, or assumes any legal liability or responsibility for the accuracy, completeness, or usefulness of any information, apparatus, product, or process disclosed, or represents that its use would not infringe privately owned rights. Reference herein to any specific commercial product, process, or service by trade name, trademark, manufacturer, or otherwise does not necessarily constitute or imply its endorsement, recommendation, or favoring by the United States Government or any agency thereof, or Battelle Memorial Institute. The views and opinions of authors expressed herein do not necessarily state or reflect those of the United States Government or any agency thereof.

\author{
PACIFIC NORTHWEST LABORATORY \\ operated by \\ BATTELLE MEMORIAL INSTITUTE \\ for the \\ UNITED STATES DEPARTMENT OF ENERGY \\ under Contract DE-AC06-76RLO 1830
}


REPORT DOCUMENTATION PAGE

\begin{tabular}{|c|c|c|c|c|c|}
\hline \multicolumn{2}{|l|}{$\begin{array}{l}\text { 1a. REPORT SECURITY CLASSIFICATION } \\
\text { Unclassified }\end{array}$} & \multicolumn{4}{|c|}{ 1b. RESTRICTIVE MARKINGS } \\
\hline \multicolumn{2}{|c|}{ 2a. SECURITY CLASSIFICATION AUTHOAITY } & \multicolumn{4}{|c|}{$\begin{array}{l}\text { Approved for public release; distribution } \\
\text { unlimited }\end{array}$} \\
\hline \multicolumn{2}{|c|}{$\begin{array}{l}\text { 4. PERFORMING ORGANIZATION REPORT NUMBER(S) } \\
\text { PNL } 6872\end{array}$} & \multicolumn{4}{|c|}{ 5. MONITORING ORGANIZATION REPORT NUMBER(S) } \\
\hline $\begin{array}{l}\text { 6a. NAME OF PERFORMING ORGANIZATION } \\
\text { Pacific Northwest Laboratory }\end{array}$ & $\begin{array}{l}\text { 6b. OFFICE SYM8OL } \\
\text { (if applicabie) } \\
\text { - }\end{array}$ & \multicolumn{4}{|c|}{ 7a. NAME OF MONITORING ORGANIZATION } \\
\hline \multicolumn{2}{|l|}{$\begin{array}{l}\text { 6C ADDRESS (City, State, and ZiP Code) } \\
\text { P. } 0 . \text { Box } 999 \\
\text { Richland, WA } 99352-0999\end{array}$} & \multicolumn{4}{|c|}{ 7b. ADDRESS (City, State, and 2IP Coote) } \\
\hline $\begin{array}{l}\text { 84. NAME OF FUNDING/SPONSORING } \\
\text { ORGANIZATION } \\
\text { U.S. Ammy Medical R\&D Command }\end{array}$ & $\begin{array}{l}\text { Bb. OFFICE SYMBOL } \\
\text { (If applicable) } \\
\text { - }\end{array}$ & \multicolumn{4}{|c|}{$\begin{array}{l}\text { 9. PROCUREMENT INSTRUMENT IDENTIFICATION NUMBER } \\
\text { Army Project Order } \star 84 P P 4865\end{array}$} \\
\hline \multicolumn{2}{|l|}{ BC AODRESS (City, State, and ZIP Code) } & \multicolumn{4}{|c|}{ 10. SOURCE OF FUNDING NUMBERS } \\
\hline \multicolumn{2}{|l|}{$\begin{array}{l}\text { Fort Detrick } \\
\text { Frederick, MD 21701-5012 }\end{array}$} & $\begin{array}{l}\text { PROGRAM } \\
\text { ELEMENT NO. } \\
63751 \mathrm{~A}\end{array}$ & $\begin{array}{l}\text { PROJECT } \\
\text { NO. 3M2- } \\
637510993\end{array}$ & $\begin{array}{l}\text { TASK } \\
\text { NO. } \\
\text { CP }\end{array}$ & $\begin{array}{l}\text { WORK UNIT } \\
\text { ACCESSION NO. } \\
003\end{array}$ \\
\hline
\end{tabular}

11. TiTLE (inciude Security Classification)

(U) Toxicology Studies on Lewisite and Sulfur Mustard Agents

12. PERSONAL AUTHOR(S)

D.L. Stewart, E.J. Sass, L.K. Fritz and L.B. Sasser

\begin{tabular}{|c|c|c|c|}
\hline $\begin{array}{l}\text { T3a. TYPE OF REPORT } \\
\text { Final }\end{array}$ & $\begin{array}{l}\text { 36. TIME COVERED } \\
\text { FROM } 9 / 18 / 84 \text { TO } 7 / 3] / 89\end{array}$ & $\begin{array}{l}\text { 14. DATE OF REPORT (Yedr, Month, Day) } \\
1989 \text { July } 31\end{array}$ & $\begin{array}{l}\text { 15. PAGE COUNT } \\
35\end{array}$ \\
\hline
\end{tabular}

16. SUPPLEMENTARY NOTATION

Mutagenicity Study of Lewisite in the Salmonella Histidine Reversion Assay

\begin{tabular}{|l|c|c|}
\hline \multicolumn{3}{|c|}{ COSATI CODES } \\
\hline FHELD & GROUP & SUB-GROUP \\
\hline 24 & 07 & \\
\hline 06 & 17 & \\
\hline
\end{tabular}

18. SUBJECT JERMS (Continue on reverse if necessary and joentify by block number)

Lewisite, Mutagenicity, Ames Test, Salmonella, RA 5

19. ABSTRACT (Continue on reverse if necersary and identify by block number)

The mutagenic potential of lewisite was evaluated in the standard plate incorporation method and by the preincubation modification of the Ames Salmonella/microsomal assay with tester strains TA97, TA98, TA100 and TA102. A11 strains were tested with activation (20 and 50 yi/ plate) and without activation. The lewisite was screened injtially for toxicity with TA98 over a range of concentrations from 0.01 to $250 \mu \mathrm{g}$ of material per plate. However, concentrations selected for mutagenicity testing were adjusted to a range of 0.003 to 5 ug/ plate because of the sensitivity of tester strain TA102, which exhibited cytotoxicity at $0.01 \mu \mathrm{g} / \mathrm{plate}$. No mutagenic response was exhibited by any of the strains in either method used. All other tester strains showed evidence of cytoxicity (reduction in mutagen response or sparse background 1 awn) at $5.0 \mu \mathrm{g} / \mathrm{plate}$ or lower.

\begin{tabular}{|c|c|c|c|}
\hline 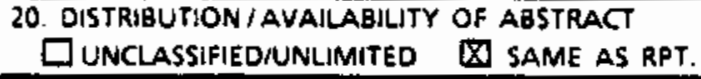 & $\square$ OTIC USERS & $\begin{array}{l}\text { 21. ABSTRACT SECURITY CLASSIFICAT } \\
\text { UnClaSs ified }\end{array}$ & ION \\
\hline $\begin{array}{l}\text { 22a. NAME OF RESPONSIBLE INDIVIDUAL } \\
\text { Mary Frances Bostjan }\end{array}$ & & $\begin{array}{l}\text { 22b. TELEPHONE (include Ared Code) } \\
\text { (301) 663-7325 }\end{array}$ & $\begin{array}{l}\text { 22c. OFFICE SYMBOL } \\
\text { SGRD-RMI -S }\end{array}$ \\
\hline
\end{tabular}


Opinions, interpretations, conclusions and recommendations are those of the author and are not necessarily endorsed by the U.S. Army.

Where copyrighted material is quoted, permission has been obtained to use such material.

Where material from documents designated for limited distribution is quoted, permission has been obtained to use the material.

u.S. Citations of commercial organizations and trade names in this report do not constitute an official Department of the Army endorsement or approval of the products or services of these organizations.

In conducting research using animals, the investigator(s) adhered to the "Guide for the Care and Use of Laboratory Animals," prepared by the Committee on Care and Use of Laboratory Animals of the Institute of Laboratory Animal Resources, National Research Council (NIH Publication No. 86-23, Revised 1985).

For the protection of human subjects, the investigator(s) have adhered to policies of applicable Federal Law 45CFR46.

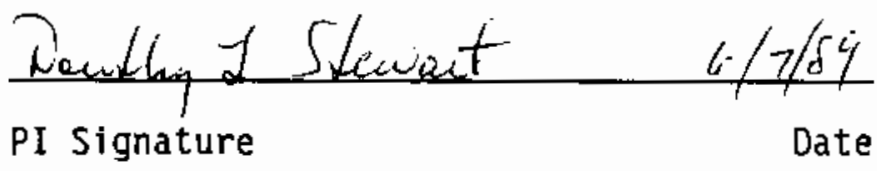




\section{EXECUTIVE SUMMARY}

Chemical warfare agents present an obvious risk to individuals suffering acute exposure, but they may a1so present long-term environmental or occupational health hazards for workers in operations involving these chemical agents. Occupational health standards have not been established for Lewisite [bis-(2-chloroethyl)-sulfide] a strong alkylating agent with known mutagenic and suspected carcinogenic properties. Lewisite is used in a number of research laboratories, stored in depot sites throughout the country and occasionally transported to distant sites. The destruction of current stockpiles of Lewisite by the U.S. Army in the near future could create additional environmental and occupational risk. To establish a database for setting environmental and occupational standards, we have conducted studies to evaluate the toxicity, mutagenicity, and reproductive effects of Lewisite using in vitro and in vivo study systems. The purpose of this study was to evaluate the mutagenic potential of Lewisite in the standard plate incorporation version and the preincubation version of the Salmonella/ microsomal assay with tester strains TA97, TA98, TA100 and TA102, with or without $S 9$ activation.

Solutions of Lewisite were prepared by diluting the neat agent to the appropriate concentrations in dimethyl sulfoxide (OMSO). Lewisite was tested at $0.001,0.005,0.01,0.1,1$ and 5 ug/plate in the standard plate incorporation version and the preincubation version of the Ames assay. Lewisite, bacterial tester strain and 59 enzyme in buffer was added to soft agar which was immediately poured onto a minimal agar plate without histidine. Positive and negative controls were included with each assay and two levels of 59 activation were evaluated. Revertant colonies were counted after incubation at $37^{\circ} \mathrm{C}$ for 48 hours. A preincubation step was used for all strains whereby al1 components of the bioassay system were incubated for 1 hour at $37^{\circ} \mathrm{C}$ prior to plating.

Lewisite did not induce a mutagenic response with any of the $S$. typhimurium tester strains at the doses tested. All strains exhibited cytotoxicity at $1.0 \mu \mathrm{g} / \mathrm{plate}$ or higher. Strain TA102 exhibited more cytotoxicity than the other strains. 


\section{TABLE OF CONTENTS}

Page

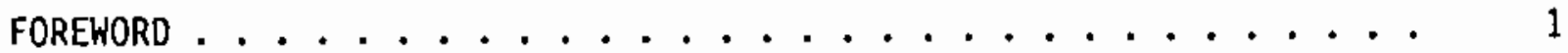

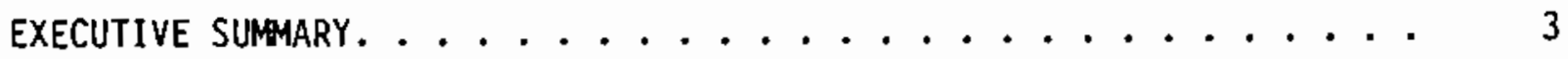

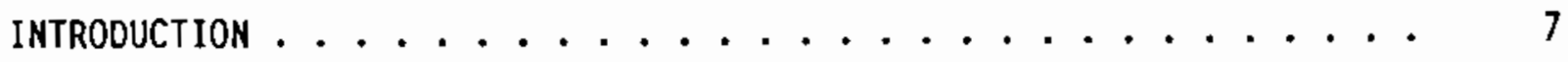

MATERIALS AND METHODS. ........................ 11

Lewisite. . . . . . . . . . . . . . . 11

Procurement and Characterization ........... 11

Analytical Procedures. .............. 11

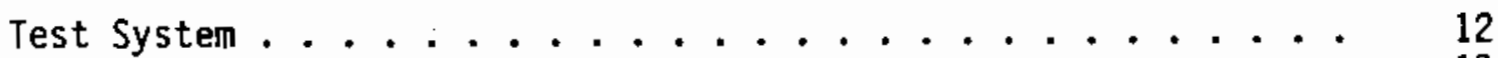

Control Articles and $S g$ Enzyme. . . . . . . . . . . 13

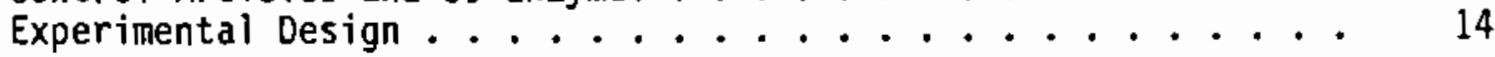

Sample Tube Preparation for Standard Plate Incorporation . . 15

Sample Tube Preparation for Preincubation Modification . . . 17

Statistical Analysis. ................. 17

RESULTS. ............................... 19

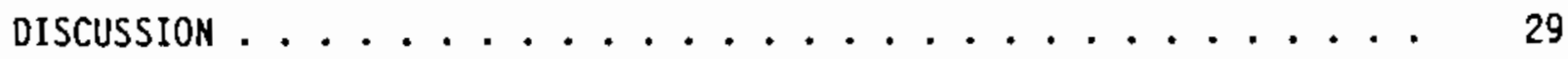

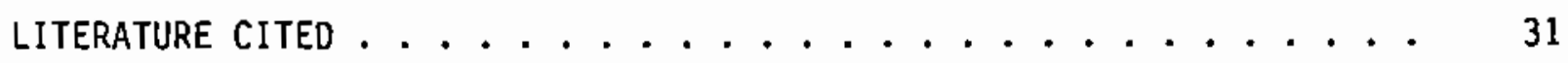

PERSONNEL LIST . . . . . . . . . . . . . . . . . . 33

QUALITY ASSURANCE STATEMENT. . . . . . . . . . . . . 34

DISTRIBUTION LIST. . . . . . . . . . . . . . . . . 35

\section{TABLES}

Page

1. Relevant Chemical and Physical Properties of Lewisite,

Bis(2-chloroethyl) Sulfide ............. 8

2. Concentrations of Control Chemicals ........... 13

3. Mutagenic Response of Control Chemicals . . . . . . . . 15 
TABLES (Continued)

Page

4. Mutagenic Response of Lewisite in the Salmonella Histidine

Reversion Assay With and Without Sg Activation (Test 1)......

5. Mutagenic Response of Lewisite in the Salmonella Histidine

Reversion Assay With and Without $\$ 9$ Activation (Test 2)......

6. Preliminary Toxicity Results with Salmonella Tester

Strain TA98. . . . . . . . . . . . . . . . . .

7. Mutagenicity of Lewisite for Salmonella Typhimurium Tester

Strains in the Preincubation Assay ..............

8. Reversion of Salmonella Tester Strains in the Standard Plate

Incorporation Method with Diagnostic Mutagens. . . . . . . . . . 26

9. Reversion of Salmonello Tester Strains in the Preincubation

Assay with Diagnostic Mutagens . . . . . . . . . . . . 


\section{INTRODUCTION}

Chemical warfare agents present an obvious risk to individuals suffering acute exposures but may also present long-term environmental or occupational health hazards for workers in operations involving these chemical agents. Lewisite [dichloro(2-chlorovinyl)arsine], one of two major vesicant agents, presents a potential for accidental or occupational exposure because it is used in a number of research laboratories, stored in depot sites throughout the country and occasionally transported to distant sites. In addition, stockpiles of Lewisite are scheduled for destruction by the U.S. Army in the near future, creating an additional potential for environmental and occupational exposure. Although considerable information is known concerning the acute effects of Lewisite, few data are available on its long-term hazards. Segments of the population that may be particularly sensitive to its toxicity include the chronically $i l 1$, the young and old, and the unborn. It is this concern that has prompted these studies to identify the potentially toxic, mutagenic and reproductive effects of Lewisite and to establish a data base for the development of hazard evaluations and occupational health standards for this chemical.

Lewisite is a highly toxic chemical vesicant. Unlike the strong alkylating vesicant sulfur mustard, Lewisite reacts with the sulfhydryl groups of proteins through its arsenic group (Cassarett and Doul1, 1986). In the presence of water or alkalies, Lewisite hydrolyzes to form Lewisite oxide, which is non-volatile and insoluble in water. Although few data are available, Lewisite oxide is generally thought to be a weaker vesicant (Gates et al., 1946) but its toxicity, has yet to be comprehensively studied. Relevant chemical and physical data for Lewisite are summarized in Table 1.

A comprehensive review which summarized the chemical and toxicity data of Lewisite acquired during World War I and World War II was published in 1946 (Gates et a1., 1946). This review compared known human and animal data and concluded that sufficient toxicologic data were available for the determination of military usage. Lewisite exposure is characterized by immediate onset of pain, unlike the action of sulfur mustard in which pain may be delayed. The mucous membranes of the respiratory and gastrointestinal 
TABLE 1. Relevant Chemical and Physical Data for Lewisite Dichloro(2-chlorovinyl) ars inea

CAS \#:

RTECS \#:

Structural formula:

Molecular weight:

Density at $20^{\circ} \mathrm{C}$ :

State:

Vapor pressure at $20^{\circ} \mathrm{C}$ :

Decomposition temperature:

Solubility in water:

Hydrolys is

Rate:

Products :
541-25-3

$\mathrm{CH} 2975000$

$\mathrm{Cl}-\mathrm{CH}=\mathrm{CH}-\mathrm{AsCl}_{2}$

207.39

$1.888 \mathrm{~g} / \mathrm{ml}$

Dark, oily liquid

(stable in steel and glass)

$0.394 \mathrm{~mm}$

$>100^{\circ} \mathrm{C}$

Very slightly soluble

Rapid

Chlorovinyl arsenous oxide, $\mathrm{HCl}$

(in acid solutions)

Acetylene, sodium arsenate

aRosenblatt et al. 1975

tracts are particularly sensitive to Lewisite damage. Lewisite is not only a lethal vesicant but is also a systemic toxin; the liver, kidneys, gall bladder, bile duct and other organ systems are vulnerable to damage if absorption occurs (Cameron et a1. 1946).

Exposure to Lewisite vapor produces edema of the respiratory tract and accumulation of pleural fluid (Gates et al., 1946). Skin lesions resulting from contact with liquid Lewisite involve the rapid formation of an erythematous area, subsequent vesication and penetration of subcutaneous tissue so that edema and necrosis are evident. Man was less sensitive to skin lesion induction than the dog or rabbit. Systemic intoxication was evident in the $\operatorname{dog}$ a few hours following application of Lewisite (Gates et al., 1946). Although sufficient anatomical lesions to characterize the immediate cause of death were not apparent, it was reported that fluid losses due to changes in capillary permeability did cause remarkable decreases in blood volume. Comparisons of toxic effects of Lewisite and sulfur mustard in dogs and rabbits indicate that Lewisite was more damaging to the skin and was more likely to induce systemic poisoning than was sulfur mustard. 
Few data are available to evaluate the potential chronic effects of Lewisite other than information based on anecdotal evidence from war use. Based on one incidence of accidental exposure to a soldier's leg, Lewisite is considered a suspect carcinogen in man (Krause and Grussendorf, 1978). Workers of a Japanese factory producing mustard and Lewisite agents during World War II had a high mortality rate due to respiratory and gastrointestinal cancers (Wada et al., 1968; Yamakido et al., 1985). These workers were potentially exposed to unknown quantities of both sulfur mustard and Lewisite; therefore, it is not possible to implicate Lewisite as a carcinogen because of possible confounding effects of the carcinogen sulfur mustard.

Virtually no data were found on the mutagenicity of Lewisite in the literature. Auerbach (1947) found no mutagenic response in the fruit fly exposed to Lewisite and Loveless (1951) reported normal cellular division in root tips exposed to aqueous solutions of Lewisite. The teratogenic potential of Lewisite was studied by Hackett et al. (1987) in rats and rabbits using a segment II teratology protocol. Rats were exposed to 0.5, 1.0 or $1.5 \mathrm{mg} / \mathrm{kg}$ Lewisite via gastric intubation from 6 to 15 days of gestation $(\mathrm{dg})$ and fetuses were examined at $\mathrm{dg} 20$. No evidence of a teratogenic response to Lewisite was observed. Likewise, fetal development of the rabbit exposed to 0.07 to $0.6 \mathrm{mg} / \mathrm{kg}$ Lewisite between 6 and $19 \mathrm{dg}$ was not affected even though maternal mortality was induced. These results suggest that Lewisite is not teratogenic in the rat or the rabbit after short term exposures since fetal effects were observed only at dose levels that induced maternal toxicity.

It is of interest that many of the symptoms of Lewisite and arsenic intoxication are similar (severe inflammation of the gastrointestinal tract with electrolyte disturbances and ulceration and perforation of membranes) (NAS, 1977) and raise the possibility that the toxicity of Lewisite may result from its arsenic group. In alkaline solutions, Lewisite may hydrolyze to form acetylene and sodium arsenate. Leonard and Lauwerys (1980) reviewed the carcinogenicity, teratogenicity and mutagenicity of a wide variety of arsenic compounds. Arsenic, as sodium arsenate or arsenite, is known to be embyrotoxic and teratogenic in a number of animal species (Leonard and Lauwerys, 1980). In comparison of Lewisite and sodium arsenite toxicity in the rabbit following intravenous administration, Inns et al. (1988) reported 
that the $L_{5 g}$ is of sodium arsenite and Lewisite were not similar (7.6 and $1.8 \mathrm{mg} / \mathrm{kg}$, respectively). Furthermore, significant differences in tissue arsenic content and pathology were reported for the two chemicals.

Although very little information is available on the mutagenicity of Lewisite using in vitro systems, the mutagenicity of arsenic compounds has been reviewed (Leonard and Louwerys, 1980). In general arsenic containing compounds produced chromosomal aberrations in bacterial and mamnalian systems. No information is available for mutation induction in mammalian systems, although in bacterial systems some arsenic compounds were mutagenic while others were not.

The purpose of this study was to evaluate the mutagenic potential of Lewisite in the standard plate incorporation version and the preincubation version of the Salmonella/microsomal assay with tester strains TA97, TA98, TA100 and TA102; with and without S9 activation. 
MATERIALS AND METHODS

\section{Lewisite}

Procurement and Characterization

A shipment of $25 \mathrm{ml}$ of dichloro(2-chlorovinyl)arsine (Lewisite, Agent L) was received from the U.S. Army Medical Research Institute of Chemical Defense (USAMRICD) on 7 March 1985. The chemical (Lot No. L-U-4273-CTF-N) was prepared by distillation on 30 September 1984 at the Chemical Research and Development Center (CRDC). The agent was analyzed by nuclear magnetic resonance ( $\mathrm{H}-1$ and $\mathrm{C}-13$; CROC SOP No. 6-1-83-1, Annex $\mathrm{F}$ ) at the Research Directorate, CRDC. Results of the analyses, expressed as calculated weight percent, were 95.8 and 4.0 for trans and cis isomers of dichloro(2chlorovinyl)arsine, respectively, and 0.2 for unknown compounds.

The Lewisite was divided into two equal portions, pipetted into $30-\mathrm{ml}$ Wheaton vials, sealed and stored in secondary unbreakable containers in refrigerated storage at $\sim 6^{\circ} \mathrm{C}$. To comply with Good Laboratory Practices requirements, PNL has requested that USAMRICD retain an aliquot of this lot of Lewisite.

Lewisite was analyzed to detect the presence of common impurities, such as Lewisite oxide and the cis-trans isomers of bis(2-chlorovinyl)chloroarsine and tris(2-chlorovinyl)arsine (Rosenblatt et al., 1975). Measurement of the ultraviolet absorption spectrum of the sample in isooctane revealed that the spectrum and the absorptivity of the material at $215 \mathrm{~nm}$ agreed with published values in the literature (Rewick, et al., 1986; Mohler and Sorge, 1939) and did not indicate the presence of ultraviolet-absorbing compounds other than Lewisite. This conclusion was supported by our results from gas-chromatographic analyses of the sample following derivatization with 2-mercaptoethanol.

Analytical Procedures

Lewisite is relatively insoluble and also is rapidly hydrolyzed in water; therefore, dimethyl sulfoxide (OMSO) was employed as the diluent for dosing solutions in this study. 
The degradation of Lewisite with time in refrigerated dimethyl sulfoxide (DMSO) was evaluated after developing an assay method that was sensitive to the relevant concentrations of Lewisite and then evaluating the concentrations in such solutions as a function of storage time. Lewisite in DMSO was assayed by gas chromatography, using a capillary column and flameionization detection. Lewisite was prepared by the addition of 2mercaptoethanol; to form the thiolated derivative shown by the following reaction:

\section{$\mathrm{ClCH}=\mathrm{CHASCl}_{2}+2 \mathrm{HSCH}_{2} \mathrm{CH}_{2} \mathrm{OH} \rightarrow \mathrm{ClCH}=\mathrm{CHAS}\left(\mathrm{SCH}_{2} \mathrm{CH}_{2} \mathrm{OH}\right)_{2}+2 \mathrm{HCl}$}

The derivatized product was then separated on a gas-chromatographic column and the area of the thiolated Lewisite signal was compared with that of an internal standard, naphthalene (NAP) or 1-chloronaphthalene (ICN), with a flame ionization detector. Naphthalene was less reliable as an internal standard, but it was used in the initial studies.

At the concentration range from 0.020 to $2.000 \mathrm{mg} / \mathrm{mL}$ of Lewisite in DMSO, the average percentage of Lewisite remaining after approximately one week was $85 \%$. This indicates that Lewisite is relatively stable in DMSO over that time period. The $95 \%$ confidence interval for that percentage is 85 * 25. At concentrations below $0.20 \mathrm{mg} / \mathrm{mL}$, the degradation appeared to occur more rapidly on a relative basis, however this appearance may be deceptive since the assay cannot evaluate Lewisite concentrations accurately at those concentrations.

\section{Test System}

The mutagenic potential of Lewisite was evaluated in the standard plate incorporation method and by the preincubation modification of the Ames Salmonella/microsomal assay with tester strains TA97, TA98, TA100 and TA102. All strains were tested with activation $(20$ and $50 \mu 1 / p l a t e)$ and without activation. In-house cultures were obtained from Dr. Bruce Ames' laboratory at the University of California, Berkeley, CA 94720.

S. typhimurium is routinely used to evaluate the mutagenic potential of test chemicals. Strains TA97, TA98, TA100 and TA102 were selected based on the revised methods for the Salmonella mutagenicity test (Maron and Ames, 
1983). The two new strains, TA97 and TA102, have been genetically designed to increase their sensitivity to mutagens, which previous strains either weakly detected or did not detect at all.

\section{Control Articles and S9 Enzyme}

All control articles were dissolved in DMSO and tested at the following concentrations listed in Table 2 .

Table 2. Concentrations of Control Chemicals

\begin{tabular}{llc}
\hline & \multicolumn{1}{c}{ CAS $\#$} & $\begin{array}{c}\text { Amount } \\
\mu g / \text { plate }\end{array}$ \\
\hline 2-Aminofluorene (5-AF) & $153-78-6$ & 10 \\
Benzo[a]pyrene (BaP) & $613-13-8$ & 1.0 \\
N-methyl-N-nitro-N-nitrosoguanidine (MNNG) & $70-25-7$ & 1.0 \\
Sodium azide & $26628-22-8$ & 1.5 \\
ICR-191 & $146-59-8$ & 1.0 \\
Mitomycin C & $50-07-7$ & 0.5 \\
\hline
\end{tabular}

The 59 enzyme was prepared from 8- to 10-week-old Sprague-Dawley male rats induced with Aroclor $1254(500 \mathrm{mg} / \mathrm{kg})$ according to the procedure outlined by Maron and Ames (1983). All S9 preparations were supplied by Litton Bionetics, 2020 Bridge View Lane, Charleston, SC 29405 and stored at approximately $-80^{\circ} \mathrm{C}$ for no longer than 3 to 4 months. Each batch of 59 enzyme was checked for activity with control mutagens prior to use in the study. These results were compared to the ones supplied by Litton Bionetics and to our own historical data base. Only 59 preparations that gave similar mutagenic responses were used for the study. 


\section{Experimental Design}

Lewisite was tested at $0.001,0.005,0.01,0.05,0.1,1$ and $5 \mu \mathrm{g} / \mathrm{plate}$ in the standard plate incorporation version and the preincubtaion version of the Ames assay. Preliminary testing to determine appropriate nontoxic doses for testing was conducted with strain TA98 at three dose ranges. These sets of doses were as follows: $0.01,0.1,0.5,1,5 \mu \mathrm{g} / \mathrm{plate} ; 0.1,1,5,10,50$ $\mu \mathrm{g} / \mathrm{plate}$; and $1,10,50,100,250 \mu \mathrm{g} / \mathrm{plate}$.

Lewisite was tested against the four Ames tester strains (A97, TA98, TA100 and TA102) in the plate incorporation version of the Ames assay, with and without metabolic activation, which consisted of Aroclor 1254-induced rat liver microsomal homogenate ( $S 9$ enzyme). Two levels of $S 9$ activation (20 and $50 \mu 1 / \mathrm{plate)}$ were used for all testing performed. Although sterility controls for each batch of $S 9$ were not included for each experiment, no evidence of contamination occurred, as indicated in the background controls. Initially, the agent was assayed from 0.01 to $250 \mu \mathrm{g} / \mathrm{p}$ late of Lewisite with TA98 to find an acceptable nontoxic dose range. Results of the preliminary screening were used in setting the doses for the mutagenic evaluation of Lewisite with the other three strains.

Since cytotoxicity was observed at the higher test doses of 1 and $5 \mu \mathrm{l} /$ plate with tester strains, TA97, TA98, TA100, and at $0.01 \mu \mathrm{g}$ for TA102 in initial testing, the test doses were altered for the repeated testing to the following sets of test doses: $0.01,0.05,0.1,0.5$ and $1.0 \mu 1 / p l a t e$ for strains TA97, TA98, TA100; and $0.001,0.005,0.01,0.05$ and $0.1 \mu \mathrm{g}$ for strain TA102.

Additional testing, using the preincubation modification of the Ames assay, was conducted with all tester strains TA97, TA98, TA100, and TA102. All exposures were conducted in the Chemical Surety Material (CMS) Facility in a vented hood.

Both mutational background and mutagenicity specificity are criteria required to validate each assay conducted. Mutagenic specificity of the $S$. typhimurium test strains were determined in each experiment by the response of each strain to the positive-control chemicals. Positive control chemicals included in this study were sodium zaide at $1.5 \mu \mathrm{g} / \mathrm{plate,} \mathrm{ICR-191} \mathrm{at} 1.0 \mu \mathrm{g} /$ plate, 2-AF at $10 \mu \mathrm{g} / \mathrm{plate}$, BaP at $1.0 \mu \mathrm{g} / \mathrm{plate}$, MNNG at $1.0 \mu \mathrm{g} / \mathrm{pl}$ ate and mitomycin $C$ at $0.5 \mu \mathrm{g} / \mathrm{plate.} \mathrm{Each} \mathrm{of} \mathrm{the} \mathrm{above} \mathrm{mutagens} \mathrm{was} \mathrm{tested} \mathrm{for} \mathrm{all}$ 
strains. The quantitative reversion values were determined by incorporating the mutagens into the top agar and counting revertant colonies. Table 3 lists the mutagenic response of each control chemical and accepted background ranges as reported by Maron and Ames (1983).

Table 3. Mutagenic Response of Control Chemicals

\begin{tabular}{|c|c|c|c|c|c|c|}
\hline Mutagen & $\begin{array}{c}\text { Amount } \\
(\mu g / \text { plate })\end{array}$ & $(\mu 1)$ & TA97 & $\frac{\text { Test }}{\text { TA98 }}$ & $\frac{\text { Strains }}{\text { TA100 }}$ & TA102 \\
\hline $\mathrm{BaP}$ & 1.0 & 20 & 337 & 143 & 937 & 255 \\
\hline $2-\mathrm{AF}$ & 10.0 & 20 & 1742 & 6194 & 3026 & 261 \\
\hline Sodium azide & 1.5 & 0 & 76 & 3 & 3000 & 188 \\
\hline Mitomycin $\mathrm{C}$ & 0.5 & 0 & Inh & Inh & Inh & 2772 \\
\hline ICR-191 & 1.0 & 0 & 1640 & 185 & 185 & 0 \\
\hline Background & 0 & 0 & $90-180$ & $30-50$ & $120-200$ & $240-300$ \\
\hline
\end{tabular}

Negative solvent controls (DMSO) were included in each experiment to establish the solvent control background. As reported by Maron and Ames (1983), the ranges for the background mutation, without metabolic activation, are acceptable (Table 3). All strains were checked with each assay for the presence of the following genetic markers: ampicillin resistance, crystalviolet inhibition and histidine independence. Strain TA102 was also checked for tetracycline resistance.

Sample Tube Preparation for Standard PIate Incorporation

Top agar was melted, and $4.5 \mathrm{ml}$ amounts were put in each tube. The tubes were allowed to cool to approximately $50^{\circ} \mathrm{C}$. The top-agar tubes were placed in the dry bath outside the fume hood and transferred to the hood as needed. The remaining steps in the procedure were conducted according to the "Handiing of chemical Surety Materials in the Ames Assay." The calculated amount of test article was added to appropriate tubes. Stock solutions of the test article were prepared at $0.1,0.01,0.001,0.02,0.002$, and 0.0002 
$\mathrm{mg} / \mathrm{ml}$. Fifty- $\mu \mathrm{l}$ aliquots of these stock solutions were tested. Each dose level was assayed in triplicate, with and without the metabolic activating system.

Positive control mutagens (2-AF at $10 \mu \mathrm{g} / \mathrm{plate,} \mathrm{BaP} \mathrm{at} 1.0 \mu / \mathrm{plate,} \mathrm{MNNG}$ at $1.0 \mu \mathrm{g} / \mathrm{plate,} \mathrm{mitomycin} \mathrm{C}$ at $0.5 \mu \mathrm{g} / \mathrm{plate}$, sodium azide at $1.5 \mu \mathrm{g} / \mathrm{plate}$, and ICR-191 at $1.0 \mu \mathrm{g} / \mathrm{plate}$ ) were included in each experiment to confirm the mutagenic specificity of the tester strains. Stock concentrations of the control articles were prepared at $10,000 \mu \mathrm{g} / \mathrm{ml}$ and appropriate dilutions were made from these stock solutions. A 50- $\mu 1$ aliquot of the test chemicals and negative solvent controls was used with each experiment. For indirect activation (i.e., mutagen is activated by $\$ 9$ enzyme to active metabolites), a volume of $0.5 \mathrm{ml} \mathrm{Sg}$ buffer was added to each tube of top agar with the appropriate volume of Aroclor 1254-induced $\$ 9$ enzyme. For direct activation (i.e., mutagen does not require $\$ 9$ enzyme for activation), only $\$ 9$ buffer was added to the top agar. The same lot of $\$ 9$ enzyme was used throughout any given experiment.

A volume of $0.1 \mathrm{ml}$ of $S$. typhimurium (Ames) tester strain culture was added to each tube. The final concentration was approximately $2.5 \times 10^{8}$ cells/ml of top agar. A volume of $0.5 \mathrm{ml}$ of $\mathrm{s} 9$ buffer and either 20 or 50 $\mu 1 / p l a t e$ of Aroclor-induced $S 9$ enzyme were added to each tube for indirect activation. For direct activation (without metabolic activation), only 0.5 $\mathrm{ml}$ buffer solution was added. The top agar was gently mixed on a vortex mixer, then poured onto minimal agar plates. When the agar was solidified, the plates were transferred in sealed plastic jars to the incubators and incubated at $37^{\circ} \mathrm{C}$ for 48 hours.

The revertant colonies were counted on each plate, using a Biotran III electronic plate counter. Plate counts were transferred directly to an Apple II Plus computer for storage, statistical analysis and subsequent retrieval. The background bacterial lawn was also examined under magnification to check the cytotoxicity of the chemical; a sparse bacterial lawn with pinpoint-size visible colonies indicated a toxic dose. Revertant colonies (at least 50 colonies were transferred from $p$ lates that exhibited a mutagenic response to a minimal agar plate without histidine to check for histidine independence. 
Sample Tube Preparation for Preincubation Modification

This assay was conducted as described above, except the components of the system without top agar were incubated for 1 hour at $37^{\circ} \mathrm{C}$ before plating. At the time of plating, viability determinations were also conducted by the serial-plate-dilution method, using nutrient agar.

\section{Statistical Analysis}

Simple linear regression analysis of dose response data were performed with an Apple II Plus computer, using a program written for processing data in this laboratory. These results have been verified by using a standard program for linear regression analyses written for the Hewlett-Packard calculator. 


\section{RESULTS}

Dose response data for each Solmonella tester strain on the standard plate incorporation method are presented in Tables 4 and 5 . None of the tester strains with or without $\$ 9$ activation for both Tests 11 and $\$ 2$ gave a mutagenic response (i.e., a twofold increase over background) to Lewisite at the doses tested. Lewisite at the concentrations used was toxic for all the strains as indicated by the reduction in mutagenic response. Strains TA97 and TA100 exhibited cytotoxicity to Lewisite at the $0.5 \mu \mathrm{g} / \mathrm{plate}$ dose, while cytotoxicity for TA102 was seen at a lower dose of $0.1 \mu \mathrm{g} / \mathrm{plate}$. Cytotoxicity occurred with tester strain TA98 at a higher concentration of 1.0 $\mu \mathrm{g} / \mathrm{plate}$.

Preliminary toxicity results with tester strain TA98 are presented in Table 6. Three sets of overlapping doses $(0.01,0.1,0.5,1,5,10,50 ; 1$, $10,50,100,250 \mu \mathrm{g} / \mathrm{plate})$ were tested with three levels of activation. More cytotoxicity was observed in the absence of $S 9$ enzyme with all three sets of test doses. At the lower set of test doses $(0.01,0.10,0.5,1.0,5.0 \mu 9 /$ plate) cytotoxicity occurred at $1.0 \mu \mathrm{g}$ of Lewisite pre plate.

In Table 7, both dose response data and viability data are presented for all Solmonello tester strains in the preincubation assay. Strains TA97, TA98, and TA100 were tested at $0.01,0.05,1.0,0.5$, and $1.0 \mu 9$ of Lewisite per $m l$ of exposure medium, while strain TA102 was tested $0.001,0.005,0.01$, 0.05 , and $0.1 \mu \mathrm{g}$ of Lewisite per $\mathrm{ml}$ of exposure medium. A lower set of doses was used for TA102 because this strain exhibited more cytotoxicity in the standard plate method than the other strains. At these concentrations of Lewisite, no mutagenic response was observed for any of the Salmonella strains with or without activation. As was evident by the viability data presented in Table 7, Lewisite was toxic for Salmonello tester strains TA97, TA100 and TA102 at these doses. Only Salmonella tester strain TA98 did not exhibit cytotoxicity.

Results for the positive and negative controls are presented in Tables 8 and 9 . The underlined responses indicate the mutagens used for mutagenic specificity of the tester strains and agree with the mutagenic pattern reported by Maron and Ames (1983). Although our responses are lower than the ones reported by Maron and Ames, they agree with our historical database and 
provide confirmation of mutagenic specificity of the tester strains and confirm the reliability of the data generated by the Solmonello histidine reversions assay. 
TABLE 4. Mutagenic Response of Lewisite in the Salmonella Histidine Reversion Assay With and Without $\$ 9$ Activation (Test 1)

\begin{tabular}{|c|c|c|c|c|}
\hline \multirow{2}{*}{$\begin{array}{l}\text { Salmonella } \\
\text { Tester Strain }\end{array}$} & \multirow{2}{*}{$\begin{array}{c}\text { Concentration } \\
\text { ( } \mu \mathrm{g} / \text { /Plate })\end{array}$} & \multicolumn{3}{|c|}{ Revertants/Plate $\pm S D(N=3)$} \\
\hline & & $0 \mu 1$ 59/Plate & $20 \mu \mid$ S9/Plate & $50 \mu$ ا S9/Plate \\
\hline \multirow[t]{6}{*}{ TA97 } & 0.0 & $112 \pm 23$ & $156 \pm 20$ & $141 \pm 17$ \\
\hline & 0.01 & $97 \pm 25$ & $170 \pm 22$ & $171 \pm 28$ \\
\hline & 0.05 & $118 \pm 20$ & $160 \pm 18$ & $167 \pm 9$ \\
\hline & 0.1 & $138 \pm 16$ & $166 \pm 23$ & $162 \pm 17$ \\
\hline & 0.5 & $20 \pm 5$ & $53 \pm 20$ & $146 \pm 13$ \\
\hline & 1.0 & * $24 \pm 5$ & $* 56 \pm 30$ & $\star 217 \pm 35$ \\
\hline \multirow[t]{6}{*}{ TA98 } & 0.0 & $24 \pm 7$ & $36 \pm 4$ & $37 \pm 7$ \\
\hline & 0.01 & $28 \pm 6$ & $40 \pm 6$ & $28 \pm 8$ \\
\hline & 0.1 & $27 \pm 8$ & $32 \pm 1$ & $29 \pm 4$ \\
\hline & 0.5 & $16 \pm 4$ & $31 \pm 3$ & $28 \pm 4$ \\
\hline & 1.0 & $9 \pm 3$ & $15 \pm 6$ & $38 \pm 16$ \\
\hline & 5.0 & $9 \pm 2$ & $5 \pm 1$ & $12 \pm 2$ \\
\hline \multirow[t]{6}{*}{ TA100 } & 0.0 & $173 \pm 9$ & $166 \pm 9$ & $168 \pm 3$ \\
\hline & 0.01 & $191 \pm 10$ & $186 \pm 23$ & $172 \pm 12$ \\
\hline & 0.1 & $173 \pm 31$ & $203 \pm 21$ & $161 \pm 13$ \\
\hline & 0.5 & $52 \pm 8$ & $65 \pm 11$ & $109 \pm 5$ \\
\hline & 1.0 & $B \pm 2$ & $B \pm 3$ & $33 \pm 7$ \\
\hline & 5.0 & $8 \pm 3$ & $7 \pm 2$ & $9 \pm 1$ \\
\hline \multirow[t]{6}{*}{ TA102 } & 0.0 & $171 \pm 45$ & $195 \pm 22$ & $213 \pm 34$ \\
\hline & 0.01 & $67 \pm 10$ & $113 \pm 21$ & $147 \pm 9$ \\
\hline & 0.1 & $75 \pm 14$ & $101 \pm 8$ & $92 \pm 18$ \\
\hline & 0.5 & $22 \pm 13$ & $28 \pm 8$ & $59 \pm 23$ \\
\hline & 1.0 & $8 \pm 2$ & $7 \pm 1$ & $18 \pm 5$ \\
\hline & 5.0 & $8 \pm 3$ & $8 \pm 1$ & $10 \pm 2$ \\
\hline
\end{tabular}

*Nonrevertant colonies/pinpoint colonies from background lawn. 
TABLE 5. Mutagenic Response of Lewisite in the Salmonella Histidine Reversion Assay With and Without S9 Activation (Test 2)

\begin{tabular}{|c|c|c|c|c|}
\hline \multirow{2}{*}{$\begin{array}{c}\text { Salmonella } \\
\text { Tester 5train }\end{array}$} & \multirow{2}{*}{$\begin{array}{c}\text { Concentration } \\
(\mu \mathrm{g} / \text { Plate })\end{array}$} & \multicolumn{3}{|c|}{ Revertants/Plate \pm SD $(\mathrm{N}=3)$} \\
\cline { 3 - 5 } & 0.0 & $170 \pm 45$ & $206 \pm 20$ & $206 \pm 14$ \\
\hline TA97 & $0.0 /$ Plate & $20 \mu /$ S9/Plate & $50 \mu /$ S9/Plate \\
\hline & 0.01 & $128 \pm 12$ & $144 \pm 17$ & $180 \pm 18$ \\
\hline & 0.05 & $164 \pm 19$ & $146 \pm 9$ & $187 \pm 8$ \\
\hline & 0.1 & $158 \pm 2$ & $146 \pm 12$ & $187 \pm 5$ \\
\hline & 0.5 & $30 \pm 6$ & $35 \pm 1$ & $142 \pm 9$ \\
\hline & 1.0 & $12 \pm 4$ & $12 \pm 8$ & $57 \pm 8$ \\
\hline
\end{tabular}

\begin{tabular}{|l|l|l|r|r|}
\hline TA98 & 0.0 & $27 \pm 3$ & $30 \pm 10$ & $31 \pm 3$ \\
\hline & 0.01 & $31 \pm 3$ & $34 \pm 7$ & $40 \pm 6$ \\
\hline & 0.05 & $25 \pm 5$ & $33 \pm 5$ & $32 \pm 3$ \\
\hline & 0.1 & $26 \pm 7$ & $28 \pm 6$ & $34 \pm 6$ \\
\hline & 0.5 & $17 \pm 2$ & $9 \pm 4$ & $30 \pm 1$ \\
\hline & 1.0 & $12 \pm 3$ & $\star 12 \pm 2$ & $22 \pm 7$ \\
\hline
\end{tabular}

\begin{tabular}{|l|l|r|r|r|}
\hline TA100 & 0.0 & $180 \pm 4$ & $183 \pm 12$ & $166 \pm 7$ \\
\hline & 0.01 & $158 \pm 4$ & $142 \pm 10$ & $116 \pm 20$ \\
\hline & 0.05 & $159 \pm 9$ & $125 \pm 4$ & $107 \pm 9$ \\
\hline & 0.1 & $143 \pm 15$ & $115 \pm 10$ & $118 \pm 2$ \\
\hline & 0.5 & $32 \pm 4$ & $31 \pm 6$ & $76 \pm 10$ \\
\hline & 1.0 & $17 \pm 5$ & $10 \pm 3$ & $21 \pm 2$ \\
\hline
\end{tabular}

\begin{tabular}{|l|l|l|l|l|}
\hline TA102 & 0.0 & $130 \pm 13$ & $159 \pm 23$ & $149 \pm 9$ \\
\hline & 0.001 & $137 \pm 3$ & $118 \pm 7$ & $138 \pm 8$ \\
\hline & 0.005 & $123 \pm 11$ & $130 \pm 9$ & $126 \pm 8$ \\
\hline & 0.01 & $99 \pm 13$ & $152 \pm 18$ & $119 \pm 19$ \\
\hline & 0.05 & $86 \pm 16$ & $140 \pm 23$ & $111 \pm 4$ \\
\hline & 0.1 & $85 \pm 28$ & $100 \pm 9$ & $97 \pm 3$ \\
\hline
\end{tabular}

*Nonrevertant colonies/pinpoint colonies from background lawn. 
TABLE 6. Preliminary Toxicity Results with Salmone/la Tester Strain TA98

\begin{tabular}{|c|c|c|c|}
\hline \multirow{2}{*}{$\begin{array}{c}\text { Lewisite Concentration } \\
(\mu \mathrm{g} / \text { Plate })\end{array}$} & \multicolumn{3}{|c|}{ Revertants/Plate $\pm S D(N=3)$} \\
\hline & $0 \mu 1 \$ 9$ & $20 \mu 159$ & $50 \mu / \$ 9$ \\
\hline 0.0 & $55 \pm 4$ & $64 \pm 6$ & $63 \pm 3$ \\
\hline 0.01 & $54 \pm 6$ & $63 \pm 9$ & $53 \pm 6$ \\
\hline 0.1 & $81 \pm 28$ & $64 \pm 12$ & $68 \pm 9$ \\
\hline 0.5 & $37 \pm 17$ & $31 \pm 8$ & $67 \pm 5$ \\
\hline 1.0 & $11 \pm 2$ & $\star 55 \pm 31$ & ${ }^{*} 81 \pm 8$ \\
\hline 5.0 & $11 \pm 2$ & $10 \pm 1$ & $13 \pm 7$ \\
\hline 0.0 & $55 \pm 4$ & $64 \pm 6$ & $63 \pm 3$ \\
\hline 0.1 & $68 \pm 6$ & $67 \pm 11$ & $72 \pm 5$ \\
\hline 1.0 & $13 \pm 4$ & *39 \pm 21 & $\star 56 \pm 27$ \\
\hline 5.0 & $13 \pm 3$ & $10 \pm 3$ & $14 \pm 3$ \\
\hline 10.0 & $17 \pm 6$ & $11 \pm 2$ & $11 \pm 1$ \\
\hline 50.0 & $13 \pm 2$ & $11 \pm 1$ & $14 \pm 2$ \\
\hline 0.0 & $55 \pm 4$ & $64 \pm 6$ & $63 \pm 3$ \\
\hline 1.0 & $18 \pm 4$ & $* 53 \pm 9$ & $\star 85 \pm 6$ \\
\hline 10.0 & $13 \pm 2$ & $13 \pm 2$ & $13 \pm 3$ \\
\hline 50.0 & $14 \pm 4$ & $11 \pm 2$ & $15 \pm 3$ \\
\hline 100.0 & $13 \pm 4$ & $12 \pm 2$ & $14 \pm 2$ \\
\hline 250.0 & $13 \pm 2$ & $14 \pm 2$ & $14 \pm 1$ \\
\hline
\end{tabular}

*Nonrevertant colonies/pinpoint colonies from background lawn. 
TABLE 7. Mutagenicity of Lewisite for Salmonella typhimurium Tester Strains in the Preincubation Assay

\begin{tabular}{|c|c|c|c|c|c|c|c|}
\hline \multirow[b]{2}{*}{$\begin{array}{l}\text { Salmonella } \\
\text { Tester Strain }\end{array}$} & \multirow[b]{2}{*}{$\begin{array}{c}\text { Concentration } \\
(\mu \mathrm{g} / \mathrm{m} \mid)\end{array}$} & \multicolumn{2}{|c|}{$0 \mu \mid 59 / \mathrm{ml}$} & \multicolumn{2}{|c|}{$20 \mu \mid 59 / \mathrm{ml}$} & \multicolumn{2}{|c|}{50 ㄴ $59 / \mathrm{ml}$} \\
\hline & & $\begin{array}{l}\text { Revertants } \\
\text { Plate } \pm S D \\
(N=3)\end{array}$ & $\begin{array}{c}\text { Viable Cells/ml } \\
\text { of Exposure } \\
\text { Medium } \times 10^{6}\end{array}$ & $\begin{array}{l}\text { Revertants/ } \\
\text { Plate } \pm S D \\
(N=3)\end{array}$ & $\begin{array}{c}\text { Viable Cells/ml } \\
\text { of Exposure } \\
\text { Medium x } 10^{6}\end{array}$ & $\begin{array}{l}\text { Revertants } \\
\text { Plate } \pm S D \\
(N=3)\end{array}$ & $\begin{array}{c}\text { Viable Cells/ml } \\
\text { of Exposure } \\
\text { Medium } \times 10^{6}\end{array}$ \\
\hline \multirow[t]{6}{*}{ TA97 } & 0.0 & $117 \pm 11$ & $188 \pm 12$ & $186 \pm 14$ & $125 \pm 20$ & $184 \pm$ & $113 \pm 11$ \\
\hline & 0.01 & $83 \pm 12$ & $113 \pm 16$ & $95 \pm 19$ & $22 \pm 4$ & $168 \pm 5$ & $87 \pm 3$ \\
\hline & 0.05 & $85 \pm 3$ & $71 \pm 8$ & $144 \pm 12$ & $91 \pm 8$ & $162 \pm$ & $102 \pm 11$ \\
\hline & 0.1 & $101 \pm 13$ & $70 \pm 3$ & $106 \pm 6$ & $59 \pm 5$ & $158 \pm 13$ & $90 \pm 4$ \\
\hline & 0.5 & $35 \pm 13$ & $76 \pm 5$ & $157 \pm 11$ & $187 \pm 7$ & $123 \pm 9$ & $34 \pm 9$ \\
\hline & 1.0 & $17 \pm 4$ & $120 \pm 3$ & $71 \pm 20$ & $45 \pm 8$ & $22 \pm 7$ & $28 \pm 8$ \\
\hline \multirow[t]{6}{*}{ TA98 } & 0.0 & $23 \pm$ & $295 \pm 27$ & $34 \pm 6$ & $173 \pm 5$ & $38 \pm$ & $195 \pm 6$ \\
\hline & 0.01 & $26 \pm 7$ & $190 \pm 10$ & $44 \pm 4$ & $134 \pm 6$ & $31 \pm$ & $96 \pm 13$ \\
\hline & 0.05 & $25 \pm 6$ & $197 \pm 4$ & $44 \pm 11$ & $159 \pm 8$ & $36 \pm 8$ & $136 \pm 9$ \\
\hline & 0.1 & $25 \pm 3$ & $110 \pm 26$ & $36 \pm 9$ & $175 \pm 4$ & $32 \pm 3$ & $151 \pm 5$ \\
\hline & 0.5 & $27 \pm 6$ & $150 \pm 7$ & $31 \pm 6$ & $159 \pm 9$ & $34 \pm 8$ & $120 \pm 7$ \\
\hline & 1.0 & $13 \pm 2$ & $190 \pm 23$ & $44 \pm 16$ & $102 \pm 11$ & $27 \pm 9$ & $137 \pm 10$ \\
\hline
\end{tabular}


TABLE 7. (Continued)

\begin{tabular}{|c|c|c|c|c|c|c|c|}
\hline \multirow[b]{2}{*}{$\begin{array}{l}\text { Salmonella } \\
\text { Tester Strain }\end{array}$} & \multirow[b]{2}{*}{$\begin{array}{c}\text { Concentration } \\
(\mu \mathrm{g} / \mathrm{ml})\end{array}$} & \multicolumn{2}{|c|}{$0 \mu \mathrm{l} S 9 / \mathrm{ml}$} & \multicolumn{2}{|c|}{$20 \mu \mathrm{l} 99 / \mathrm{ml}$} & \multicolumn{2}{|c|}{$50 \mu \mathrm{l} \$ 9 / \mathrm{ml}$} \\
\hline & & $\begin{array}{l}\text { Revertants/ } \\
\text { Plate } \pm \text { SD } \\
(N=3)\end{array}$ & $\begin{array}{l}\text { Viable Cells/ml } \\
\text { of Exposure } \\
\text { Medium } \times 10^{6}\end{array}$ & $\begin{array}{l}\text { Revertants/ } \\
\text { Plate } \pm S D \\
(N=3)\end{array}$ & $\begin{array}{c}\text { Viable Cells/ml } \\
\text { of Exposure } \\
\text { Medium } \times 10^{6}\end{array}$ & $\begin{array}{l}\text { Revertants } \\
\text { Plate } \pm S D \\
(N=3)\end{array}$ & $\begin{array}{l}\text { Viable Cells/ml } \\
\text { of Exposure } \\
\text { Medium } \times 10^{6}\end{array}$ \\
\hline \multirow[t]{6}{*}{ TA100 } & 0.0 & $285 \pm 55$ & $245 \pm 24$ & $278 \pm 9$ & $208 \pm 11$ & $273 \pm 26$ & $212 \pm 20$ \\
\hline & 0.01 & $260 \pm 8$ & $76 \pm 2$ & $286 \pm 34$ & $144 \pm 10$ & $300 \pm 28$ & $145 \pm 1$ \\
\hline & 0.05 & $227 \pm 7$ & $66 \pm 8$ & $267 \pm 6$ & $110 \pm 12$ & $299 \pm 23$ & $130 \pm 4$ \\
\hline & 0.1 & $239 \pm 6$ & $66 \pm 3$ & $259 \pm 23$ & $109 \pm 13$ & $231 \pm 10$ & $74 \pm 8$ \\
\hline & 0.5 & $79 \pm 4$ & $44 \pm 9$ & $164 \pm 16$ & $36 \pm 8$ & $149 \pm 16$ & $31 \pm 5$ \\
\hline & 1.0 & $18 \pm 3$ & $50 \pm 6$ & $15 \pm 3$ & $49 \pm 3$ & $68 \pm 4$ & $30 \pm 5$ \\
\hline \multirow[t]{6}{*}{ TA102 } & 0.0 & $161 \pm 24$ & $193 \pm 37$ & $171 \pm 4$ & $69 \pm 9$ & $183 \pm 13$ & $69 \pm 15$ \\
\hline & 0.001 & $99 \pm 23$ & $280 \pm 33$ & $156 \pm 21$ & $62 \pm 12$ & $138 \pm 26$ & $107 \pm 2$ \\
\hline & 0.005 & $67 \pm 10$ & $72 \pm 14$ & $113 \pm 10$ & $55 \pm 7$ & $94 \pm 24$ & $98 \pm 11$ \\
\hline & 0.01 & $62 \pm 7$ & $85 \pm 10$ & $100 \pm 5$ & $53 \pm 4$ & $83 \pm 4$ & $90 \pm 17$ \\
\hline & 0.05 & $73 \pm 12$ & $72 \pm 7$ & $87 \pm 8$ & $78 \pm 9$ & $90 \pm 9$ & $90 \pm 5$ \\
\hline & 0.1 & $75 \pm 4$ & $60 \pm 11$ & $90 \pm 7$ & $54 \pm 5$ & $111 \pm 16$ & $67 \pm 15$ \\
\hline
\end{tabular}


TABLE 8. Reversion of Salmonella Tester Strains in the Standard Plate Incorporation Method with Diagnostic Mutagens *

\begin{tabular}{|c|c|c|c|c|c|c|c|}
\hline \multirow{2}{*}{$\begin{array}{l}\text { Control } \\
\text { Chemical }\end{array}$} & \multirow{2}{*}{$\begin{array}{c}\text { Concentration } \\
\text { ( } \mu \text { g/Plate) }\end{array}$} & \multirow[b]{2}{*}{$\$ 9(\mu l)$} & \multirow{2}{*}{$\begin{array}{c}\text { Test } \\
\text { Number }\end{array}$} & \multicolumn{4}{|c|}{ Revertants/Plate $\pm S D(N=3)$} \\
\hline & & & & TA97 & TA98 & TA100 & TA102 \\
\hline \multirow[t]{2}{*}{$\mathrm{BaP}$} & 1.0 & 20 & 1 & $354 \pm 30$ & $137 \pm 14$ & $412 \pm 48$ & $270 \pm 6$ \\
\hline & & & 2 & $372 \pm 61$ & $144 \pm 15$ & $450 \pm 31$ & $273 \pm 17$ \\
\hline \multirow[t]{2}{*}{ 2-AF } & 10.0 & 20 & 1 & $701 \pm 73$ & $1262 \pm 160$ & $1129 \pm 18$ & $340 \pm 12$ \\
\hline & & & 2 & $833 \pm 12$ & $1001 \pm 62$ & $1379 \pm 51$ & $324 \pm 57$ \\
\hline \multirow[t]{2}{*}{ Sodium azide } & 1.5 & 0 & 1 & $145 \pm 13$ & $32 \pm 13$ & $525 \pm 24$ & $128 \pm 14$ \\
\hline & & & 2 & $195 \pm 27$ & $27 \pm$ & $488 \pm 11$ & $140 \pm 20$ \\
\hline \multirow[t]{2}{*}{ Mitomycin C } & 0.5 & 0 & 1 & $5 \pm 5$ & $13 \pm$ & $13 \pm$ & $681 \pm 92$ \\
\hline & & & 2 & $11 \pm 7$ & $8 \pm$ & $18 \pm 5$ & $557 \pm 98$ \\
\hline \multirow[t]{2}{*}{ ICR 191} & 1.0 & 0 & 1 & $967 \pm 43$ & $57 \pm$ & $204 \pm 24$ & $147 \pm 21$ \\
\hline & & & 2 & $1323 \pm 93$ & $61 \pm$ & $187 \pm 24$ & $135 \pm$ \\
\hline \multirow[t]{2}{*}{ MNNG } & 1.0 & 0 & 1 & $201 \pm 24$ & $33 \pm$ & $937 \pm 98$ & $943 \pm 28$ \\
\hline & & & 2 & $416 \pm 13$ & $37 \pm$ & $1287 \pm 28$ & $928 \pm 151$ \\
\hline \multirow[t]{2}{*}{ Background } & 0 & 20 & 1 & $156 \pm 20$ & $36 \pm$ & $166 \pm 9$ & $195 \pm 22$ \\
\hline & & & 2 & $206 \pm 20$ & $30 \pm 10$ & $183 \pm 12$ & $159 \pm 23$ \\
\hline \multirow[t]{2}{*}{ Background } & 0 & 50 & 1 & $141 \pm 17$ & $37 \pm$ & $168 \pm 3$ & $213 \pm 34$ \\
\hline & & & 2 & $206 \pm 14$ & $31 \pm$ & $166 \pm 7$ & $149 \pm 9$ \\
\hline \multirow[t]{2}{*}{ Background } & 0 & 0 & 1 & $112 \pm 23$ & $24 \pm$ & $173 \pm 9$ & $171 \pm 45$ \\
\hline & & & 2 & $170 \pm 45$ & $27 \pm$ & $180 \pm 4$ & $130 \pm 13$ \\
\hline
\end{tabular}

${ }^{\star}$ Background has not been subtracted. Underscored entries represent diagnostic mutagen(s) for the strain. KEY: BaP = Benzo(a)pyrene; $2 \cdot A F=2$ aminofluorene; $M N N G=N-$ Methyl-N-Nitro-N-Nitrosoguanidine 
TABLE 9. Reversion of Salmonella Tester Strains in the Preincubation Assay with Diagnostic Mutagens *

\begin{tabular}{|c|c|c|c|c|c|c|c|c|c|c|}
\hline \multirow[b]{2}{*}{$\begin{array}{l}\text { Control } \\
\text { Chemical }\end{array}$} & \multirow[b]{2}{*}{$\begin{array}{c}\text { Concentration } \\
\text { (Hg/Plate) }\end{array}$} & \multirow[b]{2}{*}{$\begin{array}{l}59 \\
\text { (hil) }\end{array}$} & \multicolumn{2}{|c|}{ TA97 } & \multicolumn{2}{|c|}{ TA98 } & \multicolumn{2}{|c|}{ TA 100} & \multicolumn{2}{|c|}{ TA 102} \\
\hline & & & $\begin{array}{c}\text { Revertants/ } \\
\text { Płate } \pm \mathrm{SD} \\
(\mathrm{N}=3)\end{array}$ & $\begin{array}{c}\text { Viable } \\
\text { Cells/mi } \\
\text { of Exposure } \\
\text { Medium } \times 10^{6}\end{array}$ & $\begin{array}{c}\text { Revertants } / \\
\text { Plate } \pm 50 \\
(\mathrm{~N}=3)\end{array}$ & $\begin{array}{c}\text { Vtable } \\
\text { Cells/ml } \\
\text { of Exposure } \\
\text { Medium } \times 10^{6}\end{array}$ & $\begin{array}{c}\text { Revertants } \\
\text { Plate } \pm 50 \\
(N=3)\end{array}$ & $\begin{array}{c}\text { Viable } \\
\text { Cells/ml } \\
\text { of Exposure } \\
\text { Medium } \times 10^{6}\end{array}$ & $\begin{array}{c}\text { Revertants } \\
\text { Plate } \pm \text { SD } \\
(\mathbb{N}=3\rangle\end{array}$ & $\begin{array}{c}\text { Viabte } \\
\text { Cells/mi } \\
\text { of Exposure } \\
\text { Medium } \times 10^{6}\end{array}$ \\
\hline $\mathrm{BaP}$ & 1.0 & 20 & $505 \pm 37$ & $36 \pm 7$ & $373 \pm 35$ & $114 \pm 19$ & $695 \pm 14$ & $127 \pm 7$ & $266 \pm 58$ & $50 \pm 13$ \\
\hline 2-AF & 10.0 & 20 & $788 \pm 19$ & $53 \pm 5$ & $1461 \pm 102$ & $82 \pm 10$ & $1181 \pm 50$ & $59 \pm 13$ & $372 \pm 61$ & $135 \pm 6$ \\
\hline Sodium azIde & 1.5 & 0 & $128 \pm 11$ & $118 \pm 10$ & $33 \pm 10$ & $210 \pm 29$ & $501 \pm 18$ & $160 \pm 14$ & $162 \pm 6$ & $144 \pm 8$ \\
\hline Mitomycin C & 0.5 & 0 & $13 \pm 7$ & $7 \pm 2$ & $13 \pm 4$ & $35 \pm 6$ & $16 \pm 3$ & $6 \pm 4$ & $678 \pm 39$ & $68 \pm 15$ \\
\hline ICR 191 & 1.0 & 0 & $1313 \pm 231$ & $77 \pm 7$ & $92 \pm 15$ & $249 \pm 15$ & $259 \pm 19$ & $151 \pm 18$ & $153 \pm 17$ & $165 \pm 24$ \\
\hline MNNG & 1.0 & 0 & $191 \pm 14$ & $182 \pm 12$ & $38 \pm 10$ & $197 \pm 21$ & $1393 \pm 65$ & $70 \pm 3$ & $716 \pm 20$ & $125 \pm 26$ \\
\hline Background & 0 & 20 & $186 \pm 14$ & $125 \pm 20$ & $34 \pm 6$ & $173 \pm 5$ & $178 \pm 9$ & $208 \pm 11$ & $171 \pm 4$ & $69 \pm 9$ \\
\hline Background & 0 & 50 & $184 \pm 3$ & $113 \pm 11$ & $38 \pm 6$ & $195 \pm 7$ & $273 \pm 26$ & $212 \pm 20$ & $183 \pm 13$ & $69 \pm 37$ \\
\hline Background & 0 & 0 & $117 \pm 11$ & $188 \pm 12$ & $23 \pm$ & $295 \pm 27$ & $285 \pm 55$ & $245 \pm 24$ & $161 \pm 24$ & $193 \pm 37$ \\
\hline
\end{tabular}

«Background has not been subtracted. Underscored entries represent diagnostic mutagen(s) for the strain. KEY: BaP = Benzo(a)pyrene; $-\mathrm{AF}=2$ aminofluorene; $M$ NNG = N-Methyl-N-Nitro-N-Nitrosoguanidine 


\section{DISCUSSION}

In our laboratory, a chemical is considered mutagenic if: 1) it induces a response that is greater or equal to two times the experimental background (solvent control) for the day; 2) if the colonies formed were prototrophic (i.e., they were histidine revertant), and 3 ) if it shows an increasing dose response for two or more concentration $(\mu \mathrm{g} / \mathrm{plate})$ in the dose response range.

Using the above criteria, Lewisite did not induce a mutagenic response with any of the Salmonello tester strains in either the standard plate incorporation method or the preincubation assay. The lack of response in reversion of these strains may be related to the lethal effect of the arsenic component of Lewisite after hydrolysis of the agent occurs. These lethat effects could be explained by inhibition of DNA synthesis due to the interaction of residual arsenic with cellular DNA. Perhaps, the arsenic intercalates the DNA or covalently binds to the DNA causing cell death. Further testing should address a method for removal of the agent before plating the cells in the assay.

In summary, the mutagenic potential of Lewisite was evaluated in the standard plate incorporation method and by the preincubation modification of the Ames Salmonella/microsomaT assay with tester strains TA97, TA98, TA100 and TA102. All strains were tested with activation (20 and $50 \mu 1 / p l a t e)$ and without activation. The Lewisite was screened initially for toxicity with TA98 over a range of concentrations from 0.01 to $250 \mu \mathrm{g}$ of material per plate. However, concentrations selected for mutagenicity testing were adjusted to a range of 0.001 to $5 \mu \mathrm{g} / \mathrm{plate}$ because of the sensitivity of tester strain TA102, which exhibited cytotoxicity at $0.01 \mu \mathrm{g} / \mathrm{plate}$. No mutagenic response was exhibited by any of the strains in either method used. All other tester strains showed evidence of cytotoxicity (reduction in mutagenic response or sparse background $1 \mathrm{awn}$ ) at $5.0 \mu \mathrm{g} / \mathrm{plate}$ or lower. 


\section{LITERATURE CITED}

Auerbach, C. and J.M. Robson. 1947. Tests of chemical substances for mutagenic action. Proc. Royal Soc. of Edinburgh 62B: 284-291.

Cameron, G.R., H.M. Carleton and R.H.D. Short. 1946. Pathological changes induced by Lewisite and Allied Compounds. J. Pathol. Bacteriol. 58: 411-422.

Cassarett, L.J. and J. Doul1. 1986. Toxicology. The Basic Science of Poisons, 3rd Ed., MacMillan Publishers, New York, NY.

Gates, M., J.W. Williams and J.A. Zapp. 1946. Arsenicals. Chemical Warfare Agents and Related Chemical Problems, Summary Technical Report of Division 9, National Defense Research Committee, Vol. 1, Parts I and II, pp. 83-114. Washington, D.C.

Hackett, P.L., L.B. Sasser, R.L. Rommereim, J.A. Cushing, R.L. Buschbom and D.R. Kalkwarf. 1987. Teratology studies on Lewisite and sulfur mustard agents: Effects of Lewisite in rats and rabbits. AD-A187495. U.S. Army Medical Research and Development Command, Ft. Detrick, Frederick, MD.

Inns, R.H., J.E. Bright and T.C. Marrs. 1988. Comparative acute systemic toxicity of sodium arsenite and dichloro(2-chlorovinyl)arsine in rabbits. Toxicology 51: 213-222.

Krause, H. and E.I. Grussendorf. 1978. Syntony of Bowen's disease and Lewisite scar. Hautarzt 29: 490-493.

Leonard, A. and R.R. Lauwerys. 1980. Carcinogenicity, teratogenicity and mutagenicity of arsenic. Mutat. Res. 75: 49-62.

Loveless, A. 1951. Qualitative aspects of the chemistry and biology of radiomimetic (mutagenic) substances. Nature 167: 338-342.

Maron, D.M. and B.N. Ames. 1983. Revised methods for the Salmonella mutagenicity test. Mutat. Res. 113: 173-215.

Mohler, H. and J. Sorge. 1939. Chemical warfare materials. XII. Light absorption by nose and throat, lung and skin poisons in ultraviolet of short wave length. HeTv. Chim. Acta 22: 235-239.

National Academy of Science. 1977. Medical and Biologic Effects of Environmental Pollutants, Arsenic. Washington, D.C.

Rewick, R.T., M.L. Schumacher and D.L. Hayes. 1986. The uv absorption spectra of chemical agents and stimulants. Appl. Spectroscopy 40: 152-156. 
Rosenblatt, D.H., T.A. Miller, J.C. Dacre, I. Muul and D.R. Cogley (eds.). 1975. Problem definition studies of potential environmental pollutants. II. Physical, chemical, toxicological and biological properties of 16 substances. U.S. Army Medical Bioengineering Research and Development Laboratory Technical Report 7509. Ft. Detrick, Frederick, MD.

Wada, S., Y. Nishimoto, M. Miyanishi, S. Kambe and R.W. Miller. 1968. Mustard gas as a cause of respiratory neoplasia in man. The Lancet 7753: 1161-1163.

Yamakido, M. and T. Shigenobu. 1985. The causes of death in the retired workers of Okuno-Jima poison gas factory. Jpn. J. Med. 34: 311-322. 


\section{PERSONNEL LIST}

Function

Study Director

Facility Manager

Solution Preparation and Anatysis

Exposures

Laboratory Evaluations

Project Manager
Name

D.L. Stewart

M.T. Karagianes

M.T. Karagianes

L.B. Sasser

C.W. Lindenmeier

E.J. Sass

L.B. Sasser

C.W. Lindenmeier

L.K. Fritz

E.J. Sass

D.L. Stewart

L.B. Sasser

Study Dates: $\quad$ Initated: May 14, 1986

Completed: June 6, 1986

Data are property of the U.S. Army and will be archived under the Army's direction at approved facilities.

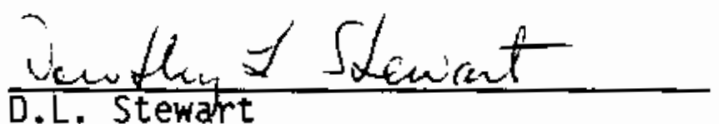

$6 / 7 / 89$ 
Mutagenicity of Lewisite in the Salmonella Reversion Test

\author{
Quality Assurance Statement
}

Listed below are the phases and/or procedures included in the study described in this report which were reviewed by the Quality Assurance Unit during the period, $5 / 15 / 86-7 / 1 / 86$, specifically for this study and the dates the reviews were performed and findings reported to management.** (All findings were reported to the study director or his designee at the time of the review.)

Phase/Procedure Reviewed

Plate Incorporation Procedure

Data

Draft Report

Final Report
Review Date

$5 / 21 / 86$

$8 / 21 \& 24 / 86$

$8 / 21,24 \& 25 / 86$

$6 / 6 / 89$
Date Findings Submitted

in Writing to

Study Director/Management

$5 / 23 / 86$

$9 / 9 / 86$

9/9/86

$6 / 7 / 89$

** Our observation of activities in the Chemical Surety Facility were limited to those conducted in the hood in room 196. These activities were observed by closed-circuit television.

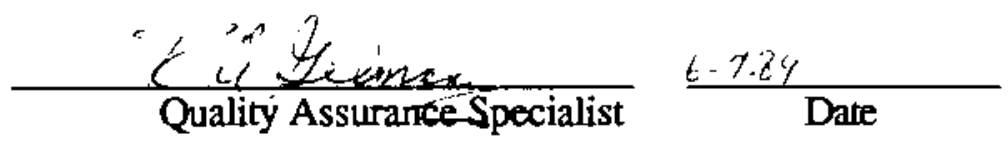


OFFSITE

Commander (25)

U.S. Army Biomedical Research and Development Laboratory

Attn: SGRD-UBZ-RA

Fort Detrick

Frederick, MD 21701-5010

Commander (2)

U.S. Army Medical Research and Development Command

Attn: SGRD-PLE

Fort Detrick

Frederick, MD 21701-5012

Commander (2)

U.S. Army Medical Research Institute of Chemical Defense

Attn: SGRD-UV-ZB

Aberdeen Proving Grounds, MD 21010-5425
Commander (2)

U.S. Army Medical Research and Development Command

Attn: SGRD-RMI-S

Fort Detrick

Frederick, MD 21701-5012

Chemical Effects Information Center (1)

Oak Ridge National Laboratory

P.0. Box $X$

0ak Ridge, TN 37831

Defense Technical Information Center (DTIC)

Attn: DTIC-DDA

Cameron Station

Alexandria, VA 22314

\section{ONSITE}

DOE/Richland Operations Office (2)

E.C. Norman/D.L. Sours

Pacific Northwest Laboratory

Publishing Coordination

Technical Reports File (5)

D.L. Stewart (3)

L.B. Sasser (3) 


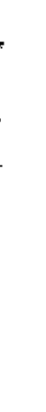

